Juan C. Solarte-Toro, Juan M. Romero-García, Ana Susmozas, Encarnación Ruiz, Eulogio Castro* and Carlos A. Cardona-Alzate

\title{
Techno-economic feasibility of bioethanol production via biorefinery of olive tree prunings (OTP): optimization of the pretreatment stage
}

https://doi.org/10.1515/hf-2018-0096

Received April 28, 2018; accepted October 19, 2018; previously published online November 17, 2018

\begin{abstract}
The aim of this work was to evaluate the economic feasibility of the bioethanol production (BEP) based on olive tree pruning (OTP) as a biomass feedstock with optimization of the dilute acid pretreatment in focus. For this, the BEP was simulated taking into account the influence of the operating conditions of the pretreatment stage. Then, the techno-economic results were analyzed by means of the response surface methodology (RSM). The results show that lowest price of BE was $1.94 \mathrm{USD} \mathrm{1}^{-1}$ with a yield of $174.12 \mathrm{l} \mathrm{t}^{-1}$ OTP under optimal conditions. As a conclusion, the raw material cost has a strong influence in the economic feasibility of the BEP from OTP. The inclusion of other processing lines into the process would improve the process economy.
\end{abstract}

Keywords: bioethanol, biorefinery, dilute acid pretreatment, economic feasibility, olive tree pruning, optimization, process simulation

\footnotetext{
*Corresponding author: Eulogio Castro, Department Chemical, Environmental and Materials Engineering, Universidad de Jaén, Campus las Lagunillas, Jaén 23071, Spain; and Center for Advanced Studies in Energy and Environment (CEAEMA), Universidad de Jaén, Campus las Lagunillas, 23071 Jaén, Spain, e-mail: ecastro@ujaen.es Juan C. Solarte-Toro and Carlos A. Cardona-Alzate: Instituto de Biotecnología y Agroindustria, Universidad Nacional de Colombia Manizales Campus, Km 09 via al Magdalena, Manizales 170003, Colombia

Juan M. Romero-García: Department Chemical, Environmental and Materials Engineering, Universidad de Jaén, Campus las Lagunillas, Jaén 23071, Spain

Ana Susmozas: Biofuels Unit, Renewable Energies Division, CIEMAT, Avda. Complutense 40, 28040 Madrid, Spain Encarnación Ruiz: Department Chemical, Environmental and Materials Engineering, Universidad de Jaén, Campus las Lagunillas, Jaén 23071, Spain; and Center for Advanced Studies in Energy and Environment (CEAEMA), Universidad de Jaén, Campus las Lagunillas, 23071 Jaén, Spain
}

\section{Introduction}

The utilization of crude-oil, natural gas and coal contributes to $78.4 \%$ of the total energy requirements in the world and leads to carbon dioxide emissions as a contributor to the global climate change (Olivier et al. 2016; BP 2017). A better utilization of biomass for energetic purposes could contribute much to mitigate this situation (Shuit et al. 2003). European Union (EU) countries have developed different strategies to utilize more renewable resources available in each region (Gioti-Papadaki 2012). The energy production from renewable resources in EU countries has grown progressively in the last decade and reached $17 \%$ of the total energy demand in 2016 in line with the proposed targets for 2020 (Gioti-Papadaki 2012; IEA 2017). Biomass and wastes, hydropower, wind energy, solar energy and geothermal energy are sources of the sustainable energy production (REN21 2016; BP 2017), while the share of traditional biomass, biofuels and wastes amounts to $\approx 67 \%$ of the total renewable energy (Eurostat 2017; Cardona et al. 2018). There is a conflict between the utilization of biomass as a food and an energy source (Koizumi 2015; Cardona et al. 2017), which can be avoided by the utilization of residual biomass from agro-industrial processes to energetic purposes. Wood pellets, biogas, bioethanol (BE), biodiesel and syngas are examples for such energy carriers obtained from stand-alone processes (Claassen et al. 1999; Surendra et al. 2014).

Bioethanol production (BEP) has grown in EU countries mainly based on corn (42\%), wheat (33\%), sugar beet $(18 \%)$ and other cereals (7\%), which supplied $7 \%$ of the global BEP worldwide. The share of wheat and sugar beet is still growing (Eurostat 2017), while less than $0.1 \%$ of BEP is based on lignocellulosic biomass (e.g. miscanthus and switch grass). The production potential of other lignocellulosic feedstocks has been widely studied, but there are only a few facilities located in Italy and other pilot-scale plants and demonstration facilities elsewhere (ePURE 2015). BEP from lignocellulosics requires a pretreatment stage, for example, by means of diluted mineral acids (Del Campo et al. 2006). Afterwards, a saccharification stage 
via acid or enzymatic hydrolysis is necessary to convert the cellulose moiety of biomass into fermentable sugars (Humbird et al. 2011). These steps are expensive and need a high capital investment costs (Hernández et al. 2014). The enzymes costs may amount to $18-20 \%$ of the total production costs (Macrelli et al. 2012). The optimization of the process is a permanent research goal (Martínez-Patiño et al. 2017). A combination of optimization, simulation and experimental characterization is needed for further process development. Probably, biorefinery-based processes will be more successful than the stand-alone processes, because the former produce and commercialize more valued-added products besides ethanol (Moncada et al. 2016).

The most renewable energy in Spain is derived from biomass (45.5\%) followed by hydropower (IEA 2017). Moreover, BEP has grown slightly in the last years, which is based on wheat and corn (Flach et al. 2017). As an alternative, lignocellulosic waste such as olive-derived biomass could be used as energy source in combination with recovery of phenolic compounds as a value-added product (Ruiz et al. 2017). Olive tree pruning (OTP), olive leaves, olive stones and dry extracted olive pomace could be utilized to these purposes. OTP is the agro-industrial residue produced in higher amounts with more than $3 \mathrm{M} \mathrm{t}$ year $^{-1}$ (Manzanares et al. 2017) collected mainly in specific areas of southern Spain (Romero-García et al. 2014). OTP could also be a source of BEP via biorefinery as the stand-alone processes are still not economically viable (Quintero et al. 2013; Vázquez-Ojeda et al. 2013; Hernández et al. 2014; Cardona et al. 2018). The biorefinery approach includes the simultaneous production of alcohol, lipids, starches and other biopolymer-derived products (Kamm and Kamm 2004; Pfaltzgraff and Clark 2014). Moncada et al. (2016) defined biorefinery as a complex production system including biomass fractionation to obtain more than one product including bioenergy, biofuels, chemicals and other high value-added compounds. In short, the aim of this work was to evaluate the economic feasibility of the BEP based on OTP including the optimization of the diluted acid pretreatment of OTP.

\section{Materials and methods}

Lignocellulosic feedstock: OTP was described as a raw material by Martínez-Patiño et al. (2017). The OTP origin in the present work is from an area located in Cambil in Jaen (Spain). The feedstock was air-dried and milled in a knive mill to reduce its particle size until it could pass through an ASTM 40 sieve. The chemical composition analysis (extractives, glucan, xylan, arabinan, mannan, galactan and lignin) via acid hydrolysis was performed (Table 1). The total solid an ash contents were also determined according to standards of National Renewable Energy Laboratory (NREL 2017).

Process description: The BEP based on lignocellulosic biomass has been well investigated (Quintero et al. 2013). The simulated BEP consists of seven blocks: extraction, pretreatment, overliming, saccharification, concentration via evaporation, fermentation and distillation. The schematic process and the experimental results are from Martínez-Patiño et al. (2017). Moncada et al. (2014) described the modeling of BEP via the biorefinery approach. The block diagram of the BEP based on OTP is presented in Figure 1.

As the first experimental block, water extraction was performed using a trayed-column of two theoretical stages to remove water soluble components from the OTP such as monomeric sugars (e.g. glucose, xylose, arabinose and mannose), polyols (e.g. mannitol) and phenolic compounds. The latter may have inhibitory effects in the subsequent stages and, moreover, phenolics are natural antioxidants of interest in the pharmaceutical, food and cosmetic industry (Rodrigues et al. 2015; Roselló-Soto et al. 2015; Talhaoui et al. 2015). This process was carried out at $2 \mathrm{~atm}$ under adiabatic conditions, with water at $120^{\circ} \mathrm{C}$ to reach $20 \%$ solubilization of the loaded solid (see Martínez-Patiño et al. 2017). Then, the extracted material was submitted to a dilute acid pretreatment stage. The process parameters - solid-liquid ratio (S/L), temperature $(\mathrm{T})$ and acid concentration $\left(\mathrm{A}_{\text {conc }}\right)$ - were varied to find a techno-economical optimum. The experimental design according to Martínez-Patiño et al. (2017) was used (Table 2) and 17 scenarios were studied, while all data were taken from the quoted work, such as the conversion of the oligomers (glucans, xylans, etc.) into monomers (glucose, xylose, etc.), the production of inhibiting compounds (acetic acid, formic acid, furfural, etc.), the solubilization of lignin, the recovery of solids and the composition of the recovered solids. The liquid fraction from the pretreatment reactor was detoxified in the overliming block. Here, two processes were carried out: (1) Decreases the amount of furfural, 5-hydroxymethylfurfural (HMF), formic acid, acetic acid and phenols (as inhibitor compounds) by adding $\mathrm{Ca}(\mathrm{OH})_{2}\left(\mathrm{pH}=10 ; 50^{\circ} \mathrm{C} ; 1 \mathrm{~atm}\right)$. (2) The $\mathrm{pH}$ was adjusted to 4.8 with $\mathrm{H}_{2} \mathrm{SO}_{4}$ and the gypsum formed

Table 1: Olive tree pruning chemical composition (dry base).

\begin{tabular}{lr}
\hline Compounds & (\% by wt.) \\
\hline Moisture & $7.00 \pm 0.42$ \\
Cellulose & $23.59 \pm 1.22$ \\
Xylan & $11.11 \pm 0.70$ \\
Galactan & $2.20 \pm 0.10$ \\
Mannan & $1.78 \pm 0.10$ \\
Arabinan & $2.55 \pm 0.17$ \\
Lignin & $17.21 \pm 0.30$ \\
Acid insoluble & $14.97 \pm 0.30$ \\
Acid soluble & $2.24 \pm 0.10$ \\
Extractives & $23.06 \pm 0.70$ \\
Glucose & $5.30 \pm 0.30$ \\
Mannitol & $3.35 \pm 0.20$ \\
Total phenols & $2.88 \pm 0.20$ \\
Acetyl groups & $1.86 \pm 0.10$ \\
Ash & $2.70 \pm 0.40$ \\
\hline
\end{tabular}

${ }^{\mathrm{a}}$ Expressed as gallic acid equivalent (GAE). 


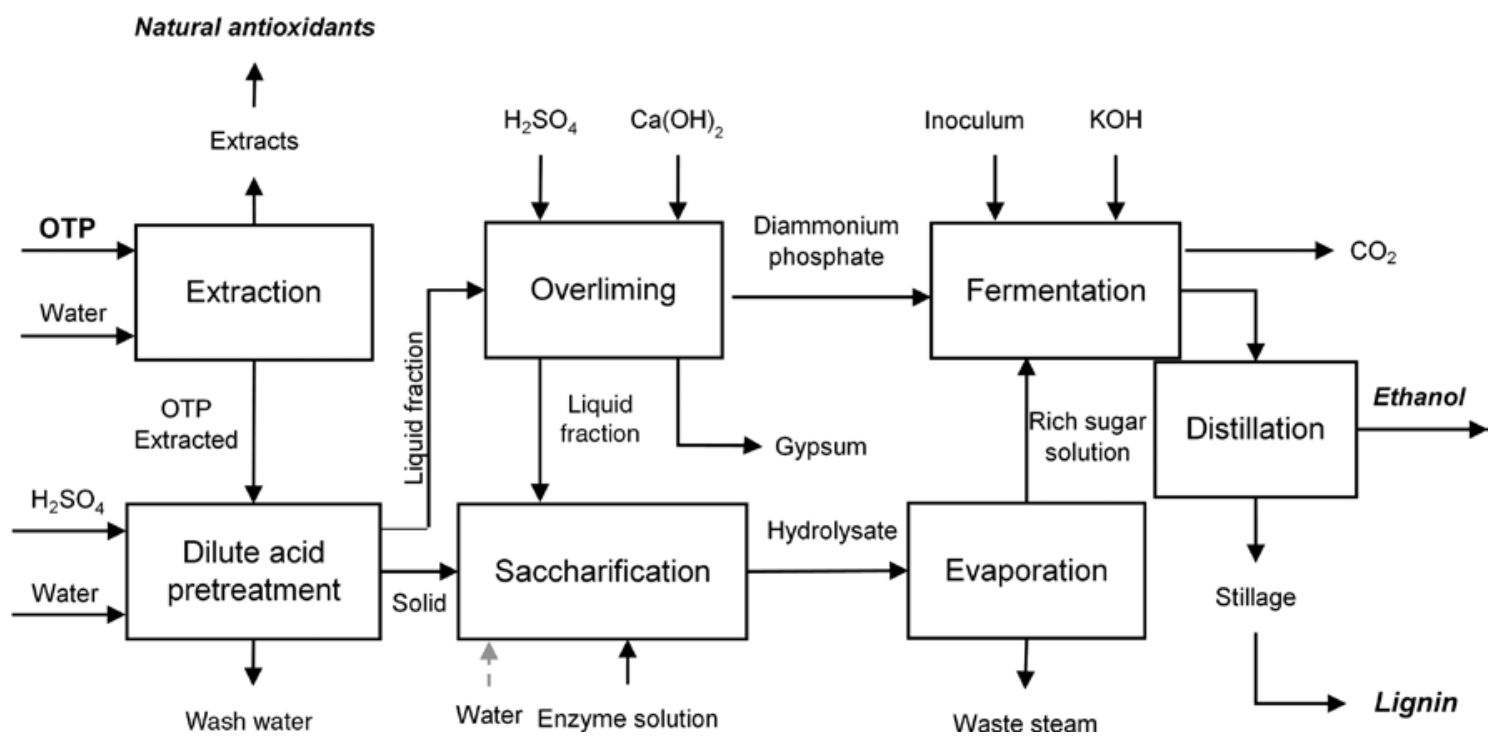

Figure 1: Block diagram of the bioethanol production from olive tree pruning (OTP) based on a biorefinery process.

Table 2: Evaluated operation conditions for the dilute acid pretreatment stage of olive tree biomass.

\begin{tabular}{|c|c|c|c|c|c|c|}
\hline \multirow[b]{2}{*}{ \# } & \multicolumn{2}{|c|}{$\mathrm{S} / \mathrm{L}$ ratio $\left(\% \mathrm{w} \mathrm{v} \mathrm{v}^{-1}\right)$} & \multicolumn{2}{|c|}{$A_{\text {conc }}\left(\mathrm{g} \mathrm{H}_{2} \mathrm{SO}_{4} 100 \mathrm{~g}^{-1}\right)^{\mathrm{b}}$} & \multicolumn{2}{|r|}{$\mathrm{T}\left({ }^{\circ} \mathrm{C}\right)$} \\
\hline & Real & Cod..$^{a}$ & Real & Cod. ${ }^{a}$ & Real & Cod. ${ }^{a}$ \\
\hline 1 & 35 & 1 & 0 & -1 & 180 & 0 \\
\hline 2 & 35 & 1 & 4 & 0 & 200 & 1 \\
\hline 3 & 15 & -1 & 4 & 0 & 200 & 1 \\
\hline 4 & 25 & 0 & 0 & -1 & 160 & -1 \\
\hline 5 & 35 & 1 & 4 & 0 & 160 & -1 \\
\hline 6 & 25 & 0 & 8 & 1 & 160 & -1 \\
\hline 7 & 15 & -1 & 0 & -1 & 180 & 0 \\
\hline 8 & 35 & 1 & 8 & 1 & 180 & 0 \\
\hline 9 & 25 & 0 & 4 & 0 & 180 & 0 \\
\hline 10 & 25 & 0 & 4 & 0 & 180 & 0 \\
\hline 11 & 25 & 0 & 4 & 0 & 180 & 0 \\
\hline 12 & 15 & -1 & 8 & 1 & 180 & 0 \\
\hline 13 & 25 & 0 & 4 & 0 & 180 & 0 \\
\hline 14 & 25 & 0 & 4 & 0 & 180 & 0 \\
\hline 15 & 25 & 0 & 0 & -1 & 200 & 1 \\
\hline 16 & 25 & 0 & 8 & 1 & 200 & 1 \\
\hline 17 & 15 & -1 & 4 & 0 & 160 & -1 \\
\hline
\end{tabular}

The parameters are given as real and coded values.

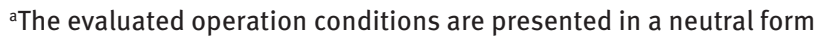
with codes, in which coded values " $-1,0$ and 1" refer to the real values or levels of the variables, $\mathrm{S} / \mathrm{L}$ ratio, $A_{\text {conc }}$ and $T$. ${ }^{\mathrm{b}} \mathrm{OTP}$.

was separated. The yields of the inhibitor compounds in the different pretreatment conditions were calculated according to MartínezPatiño et al. (2017). Subsequently, the liquid fraction from this stage and the cellu-lignin fiber from the pretreatment block were mixed in the saccharification stage, where the cellulose was degraded to glucose by the enzymatic complex composed of endo- $\beta-1,4$-glucanase, exo- $\beta-1,4$-glucanase and $\beta$-1,4-glucosidase. This process is carried out at $\mathrm{pH} 4.8$ and $50^{\circ} \mathrm{C}$ with a solids concentration not higher than
20\% w/v during $72 \mathrm{~h}$ (Cardona et al. 2018). The enzymatic hydrolysis yields of the 17 scenarios were taken from the experimental data of Martínez-Patiño et al. (2017). The outlet stream from this stage was sent to an evaporation process aiming to increase the fermentable sugars concentration up to $110 \mathrm{~g} \mathrm{l}^{-1}$ and to avoid the oversizing of the following processing stages (Paz-Astudillo 2010). Moreover, the concentration stage was considered in the BEP to always maintain the same sugar concentration in the fermentation stage. The fermentation was carried out $\left(37^{\circ} \mathrm{C}, 1 \mathrm{~atm}\right)$ by means of a genetically modified Escherichia coli MM160, which is able to ferment hexoses and pentoses (Martínez-Patiño et al. 2017). Nutrients [e.g. diammonium phosphate (DAP)] and $\mathrm{NaOH}$ were added to maintain the microorganism growth and for $\mathrm{pH}$ control, respectively. The $\mathrm{BE}$ yield estimated for the fermentation was $0.4 \mathrm{~g} \mathrm{~g}^{-1}$ of sugars $(78.4 \%$ of the theoretical yield) resulting in a value higher than $40 \mathrm{~g} \mathrm{l}^{-1}$ of $\mathrm{BE}$ during $36 \mathrm{~h}$ (proposed by Humbird et al. 2011).

Finally, the distillation stage was designed according to Humbird et al. (2011) with two distillation columns and molecular sieves. The first distillation tower is a Beer column, which concentrates the water-ethanol mixture from the fermentation block and removes the entire solid fraction formed during the previous process steps. The solid fraction removed is rich in lignin and can be upgraded to polymers, fibers, phenols, benzene, toluene and xylenes, i.e. to BTX compounds (Silva et al. 2009; Yoshikawa et al. 2012; Carvajal et al. 2016; Nowak et al. 2017). The number of theoretical stages was 10 with a reflux ratio around 1.3 (i.e. 0.5 ethanol molar fraction). The top stream from this tower is condensed and sent to a rectification column to produce an azeotropic ethanol mixture (i.e. $92 \% \mathrm{w} \mathrm{w}^{-1}$ ) under saturation conditions. Once the BE has been purified as much as possible in the rectification column, the stream is sent to molecular sieves, where it is vaporized and pressurized at $118^{\circ} \mathrm{C}$ with $1.43 \mathrm{~atm}$ (Quintero and Cardona 2011). Consequently, anhydrous ethanol $\left(>99.5 \% \mathrm{w} \mathrm{w}^{-1}\right)$ was produced and the water content was removed by adsorption (Cardona et al. 2018).

Simulation procedure and energy analysis: The mass and energy balances of the BEP were obtained by means of the Aspen Plus 
v9.0 software (Aspen Technology Inc., Bedford, MA, USA). The process was simulated with a mass flow rate of 90 OTP $t$ day $^{-1}$ (wet basis) as feedstock $\left(30,000\right.$ OTP t year $\left.^{-1}, 8000 \mathrm{~h}_{\text {year }}{ }^{-1}\right)$. The thermodynamic models non-random two liquids (NRTL) and the Hayden-O'Connell Eq. (HOC EoS) were applied, which describe the liquid and vapor phases and are able to calculate the activity and fugacity coefficients (Cardona et al. 2018). Moreover, the OTP composition (cellulose, hemicelluloses and lignin) were introduced into the simulation software manually based on the thermodynamic properties reported by NREL in Daza-Serna et al. (2016).

After calculation of the mass balances of the overall process, the energy requirements of the BOP were calculated in terms of heating and cooling conditions and steam pressures being low, medium and high, i.e. $125^{\circ} \mathrm{C} / 2.46 \mathrm{~atm}, 175^{\circ} \mathrm{C} / 8.64 \mathrm{~atm}$ and $250^{\circ} \mathrm{C} / 38.92 \mathrm{~atm}$, respectively. Furthermore, demineralized water $\left(20^{\circ} \mathrm{C}\right)$ was employed as a cooling agent. In this way, the steam and cooling water needs in heat exchangers, reboilers and condensers were obtained. Finally, the simulation tool Aspen Energy Analyzer v.9.0 was used to perform the pinch analysis of the process with hot and cold streams, aiming at the reduction of utility requirements of the process in the context of energy integration (Al-Malah 2017).

Techno-economic assessment: The technical and economic assessment of the designed BEP involves the calculation of yields, economic parameters and costs associated with the capital and operational expenditures (i.e. CAPEX and OPEX). From the technical point of view, the main parameter is the $\mathrm{BE}$ yield, which is expressed as the ratio of the amount of BE produced and the amount of feedstock employed in the process. Concerning the process profitability, the main parameters are the production costs, which are compared to the current BE market prices, as well as the utility costs, total production costs and total project capital costs. All these data were calculated by the commercial software Aspen Process Economic Analyzer v9.0 based on the mass and energy balances from the simulations. As input data of the economic evaluation, a 10-year period with an annual interest rate of 5\% was considered. In addition, the straight-line method for the capital depreciation calculation and a $25 \%$ of tax rate, were also taken into account. The operator and supervisor labor costs were $€ 20.57 \mathrm{~h}^{-1}$ and $€ 21.51 \mathrm{~h}^{-1}$, respectively, considering the Spanish context (NIS 2017). Finally, a period of $8000 \mathrm{~h}_{\text {year-1 }}{ }^{-1}$ was taken into account. The main economic assessment data is presented in Table 3.

Statistical assessment and optimization: Results from the technoeconomic and energy assessment were analyzed by the statistical software Design-Expert 8.0.7.1 (Stat-Ease Inc., Minneapolis, MN, USA). The response surface methodology (RSM) was applied, which is a collection of statistical and mathematical techniques needed for developing, improving and optimizing processes (Singh and Ghatak 2017). This methodology was extensively applied at industrial levels, particularly in situations, where several input variables influence the process performance (Myers et al. 2016). In the RSM, the real values are codified in levels and factors (Table 2), which ease calculations and increases the fit for the coefficients' estimation. To quantify the effects on the response $Y$, the following adjusted quadratic or second-order polynomial Eq. was utilized:

$$
\begin{aligned}
Y & =a_{0}+a_{1} T+a_{2} A+a_{3} S+a_{4} T A+a_{5} T S+a_{6} A S+a_{7} T^{2}+a_{8} A^{2} \\
& +a_{9} S^{2} \pm \mathrm{StD}
\end{aligned}
$$

where $T$ is for the treatment $\mathrm{T}\left({ }^{\circ} \mathrm{C}\right), A$ is the $A_{\text {conc }}\left(\mathrm{g} \mathrm{H}_{2} \mathrm{SO}_{4} 100 \mathrm{~g}^{-1} \mathrm{OTP}\right)$, $S$ is the $\mathrm{S} / \mathrm{L}$ ratio $\left(\% \mathrm{w} \mathrm{v}^{-1}\right)$, StD is the standard deviation.
Table 3: Raw material cost and utility cost used in the economic assessment.

\begin{tabular}{lrlr}
\hline Material & & Value & References \\
\hline OTP & 40.00 & USD t $^{-1}$ & 1 \\
Enzymes & 630 & USD t $^{-1}$ & 2 \\
$\mathrm{H}_{2} \mathrm{SO}_{4} 100 \%$ & 73.00 & USD t $^{-1}$ & 3 \\
Lime f.o.b $^{\mathrm{a}}$ & 65.00 & USD t $^{-1}$ & 3 \\
Cooling water & 0.04 & USD $\left.^{3}\right)^{-1}$ & 4 \\
Electricity & 0.12 & USD kWh $^{-1}$ & 4 \\
LP steam & 4.99 & USD t $^{-1}$ & 4 \\
MP steam & 5.91 & USD t $^{-1}$ & 4 \\
HP steam & 6.79 & USD t & 4 \\
Fuel & 26 & USD MW & 4 \\
\hline
\end{tabular}

OTP, Olive tree pruning.

af.o.b, Free on board; ' lime hydrated bulk. References: 1. present work; 2. Humbird et al. (2011); 3. Indicative Chemical Prices A-Z n.d.; 4. Hernández et al. (2014).

The model in Eq. (1) allows the determination of the influence of each factor on the responses as well as interactions among factors, according to the coefficients $a_{i}$. Higher absolute value of the coefficient in terms of coded values implies greater effect of the factor. The sign indicates, whether this is positive or negative in the response. $a_{0}$ indicates the response values at the central point (coded value $=0$ ). The adjustment is hierarchical, there will be only one interaction and two quadratic coefficients $\left(a_{4}-a_{9}\right)$. There are three coefficients of the factors $\left(a_{1}-a_{3}\right)$. The RSM maximizes or minimize the responses individually or jointly depending on the calculation objectives.

\section{Results and discussion}

\section{Techno-economic assessment}

The BE yield ( $\mathrm{t} \mathrm{t}^{-1}$ of OTP) was the main parameter to assess the techno-economic feasibility of the BEP under the conditions presented in Table 2. As visible in Table 4, the highest BE yield from the simulations was $140.08 \mathrm{l} \mathrm{t}^{-1}$ OTP under the conditions: $160^{\circ} \mathrm{C}, 15 \% \mathrm{w} \mathrm{v} \mathrm{v}^{-1}$ and $4 \mathrm{~g} \mathrm{H}_{2} \mathrm{SO}_{4}$ per $100 \mathrm{~g} \mathrm{OTP}^{-1}$. This BE yield is about two-fold of the lowest obtained value (i.e. $60.29 \mathrm{l} \mathrm{t}^{-1}$ OTP). Furthermore, the BE yields increase at low solids loading and acid concentrations. It can be concluded that the BE from OTP are similar to those reported for other lignocellulosic feedstocks, such as coffee cut stems (CCS), rice husk (RH), empty fruit bunches (EFB) and sugarcane bagasse (SCB), which are $292.54 \mathrm{l} \mathrm{t}^{-1}, 225.00 \mathrm{l} \mathrm{t}^{-1}, 101.15 \mathrm{l} \mathrm{t}^{-1}$, and $74.55 \mathrm{lt}^{-1}$, respectively (Quintero et al. 2013). OTP biomass could be a good BE source in comparison to EFB and SCB. Nevertheless, the yield differences are partly due to moisture content (MC) differences of the raw material. Moreover, the $\mathrm{BE}$ yield is directly connected to the holocelluloses content, 
Table 4: Techno-economic assessment results.

\begin{tabular}{|c|c|c|c|c|c|c|c|c|}
\hline$\#$ & $\begin{array}{r}\text { BE yield } \\
(\text { ( t OTP-1) }\end{array}$ & $\begin{array}{r}\text { Utility cost }{ }^{\mathrm{a}, \mathrm{b}} \\
\left(10^{3} \text { USD year }^{-1}\right)\end{array}$ & $\begin{array}{r}\text { Utility cost }{ }^{\mathrm{a}, \mathrm{c}} \\
\left(10^{3} \text { USD year- }^{-1}\right)\end{array}$ & $\begin{array}{r}\text { Total prod. cost }{ }^{\mathrm{b}, \mathrm{d}} \\
\left(10^{6} \text { USD }^{-1} \text { year }^{-1}\right)\end{array}$ & $\begin{array}{l}\text { Total prod. } \text { cost }^{\mathrm{c}, \mathrm{d}} \\
\left(10^{6} \text { USD year-1 }^{-1}\right)\end{array}$ & $\begin{array}{l}\text { BE } \cos ^{\mathrm{b}} \\
\left(\mathrm{USD} \mathrm{I}^{-1}\right)\end{array}$ & 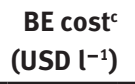 & $\begin{array}{r}\text { Total capital cost } \\
\left(10^{6} \text { USD) }\right.\end{array}$ \\
\hline 1 & 115.58 & 528.70 & 311.85 & 9.57 & 9.35 & 2.74 & 2.68 & 22.67 \\
\hline 2 & 89.43 & 525.52 & 274.05 & 9.48 & 9.23 & 3.51 & 3.41 & 22.06 \\
\hline 3 & 111.23 & 1232.82 & 678.63 & 10.95 & 10.40 & 3.26 & 3.09 & 24.57 \\
\hline 4 & 78.81 & 707.85 & 458.84 & 10.26 & 10.01 & 4.31 & 4.20 & 22.68 \\
\hline 5 & 124.07 & 421.87 & 235.80 & 9.42 & 9.24 & 2.51 & 2.46 & 22.32 \\
\hline 6 & 133.08 & 545.41 & 278.87 & 9.75 & 9.48 & 2.42 & 2.36 & 23.01 \\
\hline 7 & 131.04 & 1112.77 & 634.57 & 10.75 & 10.27 & 2.71 & 2.59 & 24.45 \\
\hline 8 & 91.94 & 466.76 & 239.64 & 9.37 & 9.15 & 3.37 & 3.29 & 21.63 \\
\hline 9 & 138.95 & 585.19 & 293.97 & 9.67 & 9.38 & 2.30 & 2.23 & 22.98 \\
\hline 10 & 129.04 & 603.18 & 302.77 & 9.77 & 9.47 & 2.51 & 2.43 & 22.85 \\
\hline 11 & 133.25 & 595.68 & 304.69 & 9.68 & 9.38 & 2.40 & 2.33 & 23.00 \\
\hline 12 & 127.15 & 1122.34 & 640.41 & 10.66 & 10.18 & 2.78 & 2.65 & 24.43 \\
\hline 13 & 129.02 & 602.60 & 313.05 & 9.66 & 9.38 & 2.48 & 2.40 & 22.93 \\
\hline 14 & 131.34 & 598.20 & 307.77 & 9.67 & 9.38 & 2.44 & 2.36 & 22.94 \\
\hline 15 & 107.07 & 704.12 & 338.91 & 9.94 & 9.57 & 3.07 & 2.96 & 23.03 \\
\hline 16 & 60.29 & 796.60 & 429.73 & 9.77 & 9.40 & 5.36 & 5.16 & 22.78 \\
\hline 17 & 140.08 & 1016.88 & 592.93 & 10.72 & 10.30 & 2.53 & 2.43 & 24.50 \\
\hline
\end{tabular}

${ }^{\mathrm{a} S t e a m}\left(\mathrm{HP}\right.$ and LP) + cooling water. ${ }^{\mathrm{b}}$ Without energy integration. ${ }^{\mathrm{c} W i t h}$ energy integration. ${ }^{\mathrm{d}}$ Total operating cost + depreciation.

i.e. the higher the better. OTP has a relatively high holocellulose content and relatively low MC at the time of production. The best BE yields can be obtained with the BEP conditions including a diluted acid pretreatment under the conditions described in line 17 of Table 2.

Another important aspect of BEP is the amount needed to satisfy the energy demand of the process, which directly affects the utility cost as well as the total production cost. The simulations considering the BEP with a high solids loading in the pretreatment stage leads to a lower utility consumption. This is due to the amount of fluids to be heated or cooled, which is lower than in the case of low solids loading. The utility cost without energy integration has a mean value $715.67 \cdot 10^{3}$ USD year $^{-1}$. The lowest and highest prices were $421.87 \cdot 10^{3} \mathrm{USD}$ year $^{-1}$ and $1232.82 \cdot 10^{3}$ USD year $^{-1}$, respectively. These results were obtained under the extremely low and high levels of solids loading, $T$, and $A_{\text {conc }}$. The energy integration analysis showed a relative high reduction in the utility cost. In general terms, the cost reduction varied from $35.2 \%$ to $51.9 \%$, which demonstrates the importance of the energy integration in the process design. The results with and without integration are comparable with those of other authors for the same process in terms of USD $1^{-1}$ of BE (Quintero et al. 2012).

The BEP cost was calculated considering the prices of raw materials, utilities, operating labor, plant overhead, maintenance and capital depreciation (Table 4). The BE costs with and without energy are within a 10\% margin, i.e. the price varies between 2.23 and $5.35 \mathrm{USD} \mathrm{l}^{-1}$. This shows the influence of the pretreatment stage and the operating conditions on the overall economic effect. It is also obvious that other variables (equipment size, operating cost and raw materials cost are more relevant than the utility cost. The BEP cost is essentially higher than the current BE price in Europe) $0.66 \mathrm{USD} \mathrm{1}^{-1}$ ). Accordingly, the stand-alone BEP based on lignocellulosics (e.g. OTP) is not competitive. The BE prices could be reduced. If the production of value-added products such as antioxidants and lignin would be included into the economic analysis.

The total project capital cost of the BEP has a mean value of $22 \cdot 10^{6} \mathrm{USD}$, which is in agreement with the economic assessments reported by Cardona et al. (2018) and Moncada et al. (2014), who reported a total project cost of $73 \cdot 10^{6}$ USD and $56 \cdot 10^{6}$ USD for two biorefineries with $200 \mathrm{t} \mathrm{h}^{-1}$ and $10 \mathrm{t} \mathrm{h}^{-1}$ of feedstock mass flow, respectively. The presented results could have an uncertainty between of 30 and $50 \%$ associated with the capital investment calculations due to the complexity of the analysis (Ghanta et al. 2013a,2013b), thus they have to be interpreted with caution.

\section{Response surface models (RSMs)}

Table 5 summarizes the model coefficients in terms of coded values obtained from the analysis of variance (ANOVA) table for several responses, together with the corresponding statistic parameters, $R^{2}$, Adj. $R^{2}$, StD and coefficient of variation (CV). $\mathrm{R}^{2}$ data indicate the reproducibility 
Table 5: Coefficients of mathematical model Eq. (1) using coded values for different responses.

\begin{tabular}{|c|c|c|c|c|c|c|c|c|}
\hline$\#$ & $\begin{array}{l}\text { BE yield } \\
\left(\text { ( t } \text { OTP }^{-1}\right)\end{array}$ & $\begin{array}{r}\text { Utility cost }{ }^{\mathrm{a}, \mathrm{b}} \\
\left(10^{3} \text { USD year }^{-1}\right)\end{array}$ & $\begin{array}{l}\text { Utility cost }{ }^{\mathrm{a}, \mathrm{c}} \\
\left(10^{3} \text { USD year }^{-1}\right)\end{array}$ & $\begin{array}{l}\text { Total prod. cost }{ }^{b, d} \\
\left(10^{6} \text { USD year }^{-1}\right)\end{array}$ & $\begin{array}{l}\text { Total prod. cost }{ }^{c, d} \\
\left(10^{6} \text { USD year }^{-1}\right)\end{array}$ & $\begin{array}{l}B E \operatorname{cost}^{\mathrm{b}} \\
\left(\mathrm{USD} \mathrm{I}^{-1}\right)\end{array}$ & $\begin{array}{l}\text { BE cost }^{c} \\
\left(\text { USD I-1) }^{-1}\right)\end{array}$ & $\begin{array}{r}\text { Total capital cost } \\
\left(10^{6} \text { USD }\right)\end{array}$ \\
\hline Transf. & Inverse & & $10 \log$ & & & & & \\
\hline$a_{0}$ & $7.65 E-03$ & 596.97 & 2.48 & 9.70 & 9.41 & 2.46 & 2.38 & 22.94 \\
\hline$a_{1}$ & $1.44 E-03$ & 62.46 & 0.023 & 0.056 & 0.005 & 0.428 & 0.397 & -0.088 \\
\hline$a_{2}$ & $5.66 \mathrm{E}-04$ & -15.29 & -0.028 & -0.063 & -0.067 & 0.095 & 0.086 & -0.203 \\
\hline$a_{3}$ & $9.97 E-04$ & -309.32 & -0.191 & -0.655 & -0.523 & 0.064 & 0.092 & -1.159 \\
\hline$a_{4}$ & $3.11 \mathrm{E}-03$ & 63.73 & 0.080 & - & - & 1.044 & 1.012 & - \\
\hline$a_{5}$ & $5.26 \mathrm{E}-04$ & -44.92 & - & - & - & 0.067 & 0.073 & -0.083 \\
\hline$a_{6}$ & $4.98 E-04$ & -17.88 & -0.030 & - & - & 0.228 & 0.225 & -0.253 \\
\hline$a_{7}$ & $2.09 E-03$ & 50.00 & 0.034 & 0.092 & 0.079 & 0.651 & 0.625 & 0.084 \\
\hline$a_{8}$ & $-1.79 E-03$ & 41.52 & 0.051 & - & - & 0.684 & 0.663 & - \\
\hline$a_{9}$ & $-6.90 E-04$ & 169.15 & 0.087 & 0.365 & 0.315 & -0.154 & -0.156 & 0.342 \\
\hline$R^{2}$ & 0.999 & 0.999 & 0.996 & 0.990 & 0.988 & 0.999 & 0.999 & 0.995 \\
\hline Adj. $R^{2}$ & 0.998 & 0.999 & 0.993 & 0.985 & 0.983 & 0.998 & 0.998 & 0.991 \\
\hline StD & $1.12 \mathrm{E}-04$ & 6.538 & 0.013 & 0.064 & 0.056 & 0.037 & 0.035 & 0.086 \\
\hline CV (\%) & 1.237 & 0.891 & 0.520 & 0.647 & 0.584 & 1.227 & 1.201 & 0.374 \\
\hline
\end{tabular}

-, No statistical significance (P-value $<0.05)$. aSteam (HP and LP) + cooling water. ${ }^{b}$ Without energy integration. 'With energy integration.

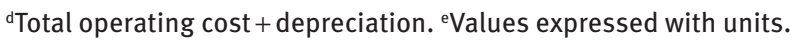

of experimental data for the model. Adj. $\mathrm{R}^{2}$ is similar to $\mathrm{R}^{2}$ but considers also the sample size and the number of model parameters. $\mathrm{R}^{2}$ is always higher and increases with the degree of freedom. These two statistical parameters take values from 0 to 1 and must have similar values. StD and $\mathrm{CV}$ show the margin of error and the relative error in the prediction of the models, respectively. Therefore, responses with low absolute values and tend to give high $\mathrm{CV}$, although the StD is small.

The model fit is significant (P-value $<0.05$ ), whose $\mathrm{P}$-values were $<0.0001$, meaning that the model is reliable in more than $99.99 \%$. Lack of fit is not significant (P-value $>0.05$ ). Therefore, the model describes appropriately the relation between the dependent and independent variables. The reproducibility of the results is good with $R^{2} \geq 0.98$ and Adj. $R^{2} \geq 0.98$. In terms of the model precision, the prediction is very good with an acceptable StD value and $\mathrm{CV}<1.5 \%$ in all responses. According to Granato et al. (2014), a model can be considered adequate when the StD is small and the $\mathrm{CV}<10 \%$, and the correlations are excellent with $\mathrm{R}^{2}>0.9$. In summary, the models in Table 5 are suitable to analyze the results and the effects of the main parameters in the search for a techno-economic optimum of the BEP based on OTP.

Figure 2 summarizes the main results of the economic analysis performed through RSM. For the responses "BE yield" and "Utility cost*", a data transformation was necessary to be analyzed by ANOVA (inverse and base $10 \mathrm{log}$, respectively). For "BE yield", the factor with the greatest effect is the $T$ along with the
$A_{\text {conc }}$ as shown by the higher values of the coefficients $\left(a_{1}, a_{4}, a_{7}, a_{8}\right)$, and as it also can be seen in Figure 2a, the three factors have an inversely proportional effect on the response (positive coefficients), that is, when the factors increase the response decreases. For the response "BE cost", the values with and without energy integration are very similar. The biggest difference is in the case of the coefficient $a_{3}$ (S/L ratio), which is $30 \%$ higher with energy integration $\left(a_{3}>a_{2}\right)$ and without energy integration $\left(a_{2}>a_{3}\right)$. As in the "BE yield" response, the factor with the greatest effect is the $T$ along with the $A_{\text {conc }}$, as shown by the values of $a_{1}, a_{4}, a_{7} a_{8}$, while the effect of the S/L ratio is very minor (Figure $2 \mathrm{~b}$ ). The three factors have a direct effect on the response (positive coefficients), that is, increasing the factors increases the "BE cost".

Concerning the "utility cost" response, a direct comparison of the effects of energy integration is not possible, but it is visible that energy integration and the $A_{\text {conc }}$ becomes more influential than the temperature $\left(a_{2}>a_{1}\right.$ y $a_{8}>a_{7}$ ). The most influential factor is the S/L ratio as shown by its coefficients ( $a_{3}$ and $a_{9}$ ), which is also illustrated in Figure 2c. As expected, the $T$ has a direct positive relation to the "utility cost", while the other two factors have a reverse net behavior.

In "total BEP cost", the coefficients are very similar irrespective of the energy integration, with the exception of the coefficient $a_{1}(T)$ that has been reduced to a tenth in the case of energy integration. As happened in the response "utility cost", the most influential factor is the S/L ratio as shown by its coefficients $\left(a_{3}\right.$ and $\left.a_{9}\right)$ (T is the least 

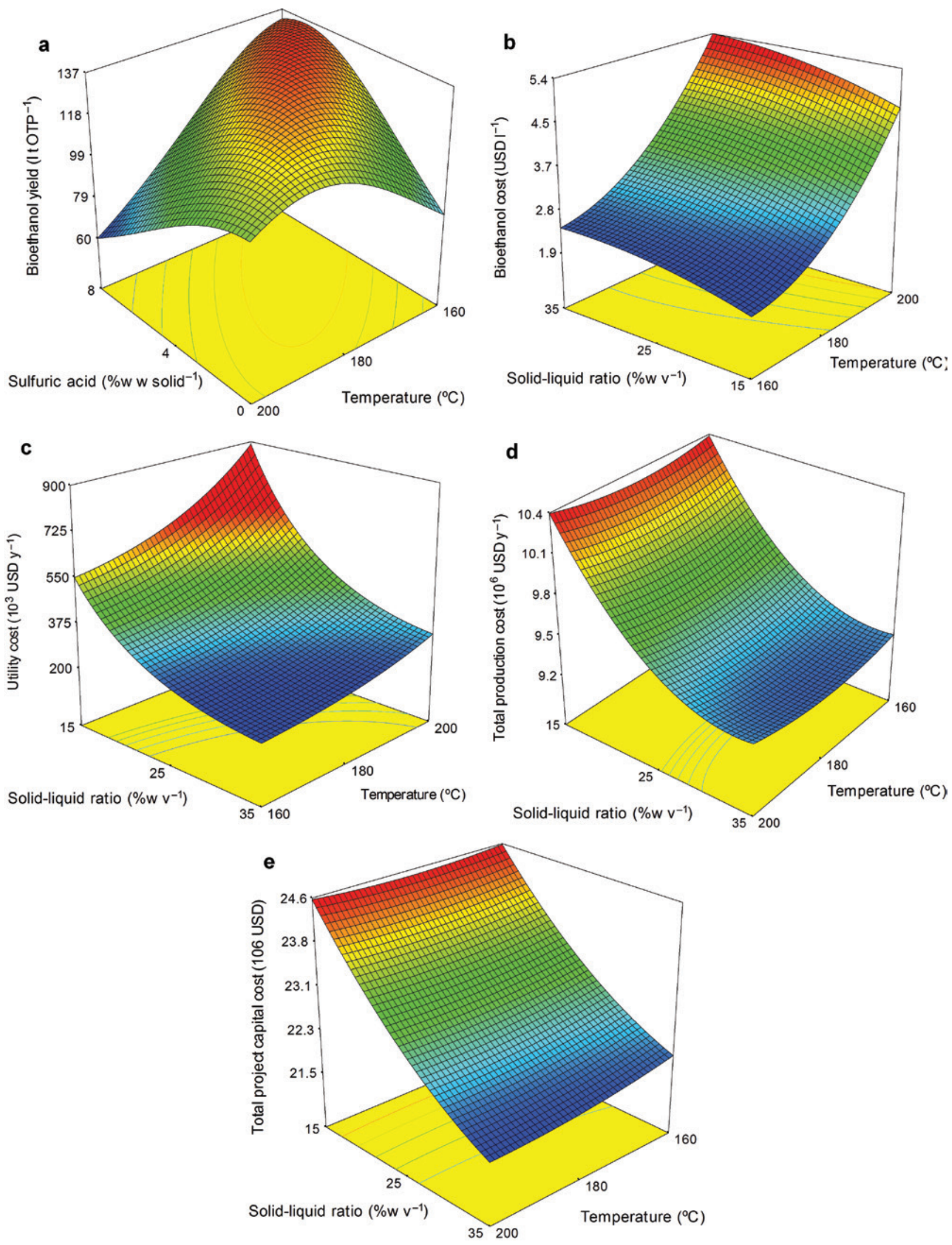

Figure 2: Response surfaces including energy parameters.

(a) Ethanol yield ( $25 \% \mathrm{~S} / \mathrm{L}$ ratio), (b) $\mathrm{BE}$ cost $\left(8 \% A_{\text {conc }}\right)$, (c) utility cost $\left(8 \% A_{\text {conc }}\right)$, (d) total production cost $\left(0 \% A_{\text {conc }}\right)$, (e) total project capital cost $\left(8 \% A_{\text {conc }}\right)$. 
Table 6: Values of the operational variables at which the optimized responses are reached.

\begin{tabular}{|c|c|c|c|c|c|}
\hline Condition & $\begin{array}{r}\text { BE yield } \\
\text { (maxim.) }\end{array}$ & $\begin{array}{r}\text { BE cost } \\
\text { (minim.) }\end{array}$ & $\begin{array}{r}\text { Utility cost }{ }^{\mathrm{a}} \\
\text { (minim.) }\end{array}$ & $\begin{array}{r}\text { Total prod. cost }{ }^{\mathrm{b}} \\
\text { (minim.) }\end{array}$ & $\begin{array}{r}\text { Total capital cost } \\
\text { (minim.) }\end{array}$ \\
\hline$T\left({ }^{\circ} \mathrm{C}\right)$ & 168.42 & 161.98 & 160.00 & 179.42 & 199.98 \\
\hline$A_{\text {conc }}\left(\mathrm{g} \mathrm{H}_{2} \mathrm{SO}_{4} \cdot 100 \mathrm{~g}^{-1 \mathrm{c}}\right)$ & 5.93 & 7.17 & 8.00 & 8.00 & 8.00 \\
\hline $\mathrm{S} / \mathrm{L}$ ratio $\left(\% \mathrm{w} \mathrm{v}^{-1}\right)$ & 15.00 & 15.00 & 35.00 & 33.29 & 35.00 \\
\hline
\end{tabular}

Maxim., Maximized; minim., minimized.

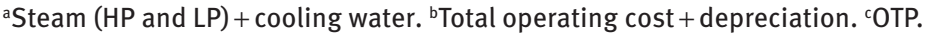

Table 7: Maximum or minimum value of the responses according to the proposed models.

\begin{tabular}{|c|c|c|c|c|c|c|c|}
\hline \multicolumn{3}{|c|}{ Optimized conditions } & \multirow{2}{*}{$\begin{array}{l}\text { BE yield I t }{ }^{-1} \\
\text { OTP (max.) }\end{array}$} & \multirow{2}{*}{$\begin{array}{r}\text { BE cost USD } \\
I^{-1}(\min .)\end{array}$} & \multirow{2}{*}{$\begin{array}{l}\text { Utility cost }{ }^{a} 10^{3} \\
\text { USD year }^{-1}(\min .)\end{array}$} & \multirow{2}{*}{$\begin{array}{r}\text { Total prod. } \operatorname{cost}^{\mathrm{b}} 10^{3} \\
\text { USD year-1 }^{-1} \text { (min.) }\end{array}$} & \multirow{2}{*}{$\begin{array}{r}\text { Total capital cos } \\
10^{3} \text { USD (min.) }\end{array}$} \\
\hline$T\left({ }^{\circ} \mathrm{C}\right)$ & $A_{\text {conc }}\left(\mathrm{g} \cdot 100 \mathrm{~g}^{-1}\right)$ & $S / L\left(\% w \cdot v^{-1}\right)$ & & & & & \\
\hline 168.42 & 5.93 & 15.00 & 174.83 & 172.44 & 127.69 & 94.02 & 55.66 \\
\hline 161.98 & 7.17 & 15.00 & 1.96 & 1.93 & 2.44 & 3.24 & 5.40 \\
\hline 160.00 & 8.00 & 35.00 & 562.09 & 555.08 & 200.98 & 236.94 & 321.89 \\
\hline 179.42 & 8.00 & 33.29 & 10.24 & 10.25 & 9.21 & 9.12 & 9.22 \\
\hline 199.98 & 8.00 & 35.00 & 24.50 & 24.56 & 21.93 & 21.81 & 21.58 \\
\hline
\end{tabular}

T, Temperature; $A_{\text {conc }}$, acid concentration; S/L, solid/liquid ratio; ${ }^{a}$ steam (HP and LP) + cooling water; btotal operating cost and depreciation. Bold face values represent maximum or minimum value in the respective row.

influential factor), Figure $2 \mathrm{~d}$. The behavior of the factors, directly proportional to $T$ and inversely proportional for the other two, also coincides with "utility cost”. Finally, in "total project capital cost", the most influential factor is the S/L ratio together with $A_{\text {conc }}$, but their influence is less pronounced as visible on the model coefficients $\left(a_{2}, a_{3}, a_{6}, a_{9}\right)$, Figure 2e, where the reduced influence of $T$ is also obvious. The three factors have an inversely proportional effect on the response (negative coefficients), that is, with increasing factors the "total project capital cost" decreases.

\section{Process optimization}

The optimal operational conditions of the five responses studied (with energy integration) are listed in Table 6 according to the optimization criteria. The optimization was directed to the maximization of the response "BE yield", while responses "BE cost", "utility cost", "total production cost", and "total project capital cost" were minimized. As seen in Table 6, optimized operational conditions cover a relatively wide range of the parameters, namely $160-200^{\circ} \mathrm{C} \mathrm{T}, 5.9-8 \mathrm{~g} \mathrm{H}_{2} \mathrm{SO}_{4}$ per 100 g OTP, and $15-35 \mathrm{~S} / \mathrm{L}$ ratio. If the $T$ values are compared, the optimized values of this factor for "BE yield", "BE cost" and "utility cost" were within the lower range, while "total production cost" and "total project capital cost" were in the middle and high range. For the $A_{\text {conc }}$ factor, is the optimized value was above the central point of the responses related to costs and is only less than $6 \%$ for the case "BE yield". Regarding the $\mathrm{S} / \mathrm{L}$ ratio, the responses can be subdivided: (1) "BE yield" and "BE cost", with the lowest ratio of $15 \%$, and (2) "utility cost", "total production cost", and "total project capital cost") are in the high value range close to $35 \%$.

While Table 6 shows the values of the operational conditions leading to optimal responses, Table 7 summarizes the optimized results. The maximum of "BE yield"

Table 8: Comparison between the techno-economic results predicted by the RSM approach and those obtained by simulation for the optimum BE yield and BE cost.

\begin{tabular}{|c|c|c|}
\hline Parameter & & Value \\
\hline$T\left({ }^{\circ} \mathrm{C}\right)$ & & 165.01 \\
\hline$A_{\text {conc }}\left(\mathrm{g} \mathrm{H}_{2} \mathrm{SO}_{4} 100 \mathrm{~g}^{-1} \mathrm{OTP}\right)$ & & 6.63 \\
\hline $\mathrm{S} / \mathrm{L}$ ratio $\left(\% \mathrm{w} \mathrm{v}^{-1}\right)$ & & 15.00 \\
\hline Parameter & RSM & Simulation \\
\hline BE yield (l t OTP-1) & 174.12 & 172.49 \\
\hline$B E \operatorname{cost}\left(\mathrm{USD} \mathrm{l}^{-1}\right)$ & 1.94 & 1.95 \\
\hline Utility cost ${ }^{a}\left(10^{3}\right.$ USD year $\left.^{-1}\right)$ & 558.36 & 524.64 \\
\hline Total production $\operatorname{cost}^{\mathrm{b}}\left(10^{6} \mathrm{USD}_{\text {year }}{ }^{-1}\right)$ & 10.24 & 10.18 \\
\hline Total project capital cost (106 USD) & 24.53 & 24.52 \\
\hline
\end{tabular}

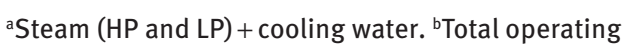
cost + depreciation. 

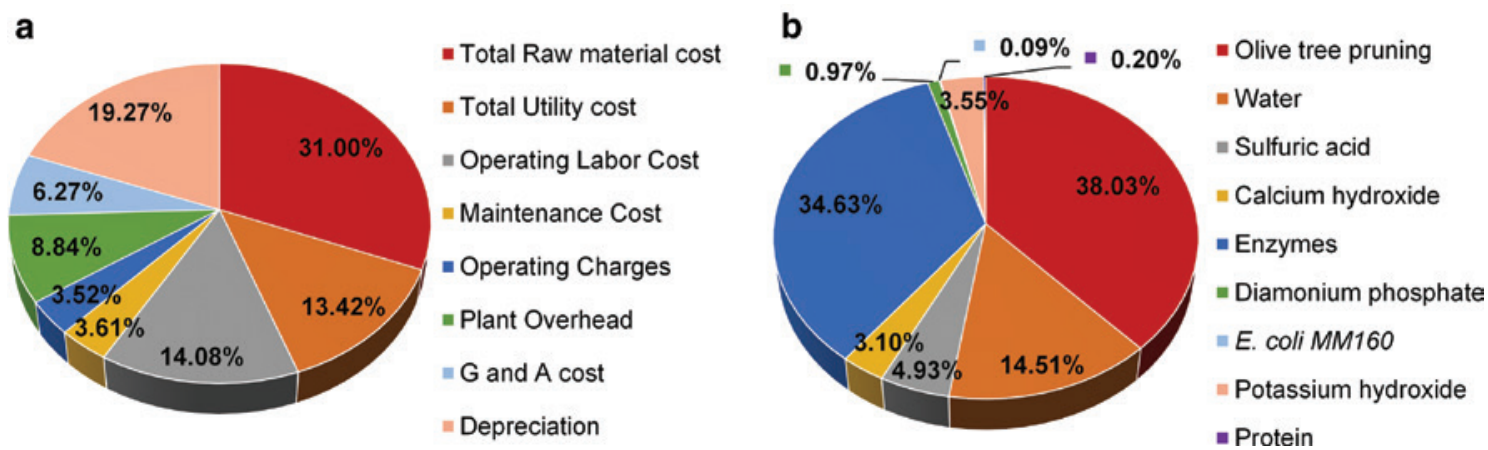

Figure 3: Economic results under optimal conditions: (a) distribution of BEP costs, (b) distribution of raw materials cost.

was $174.83 \mathrm{l} \mathrm{t}^{-1} \mathrm{OTP}$, which is triple of the value obtained for the minimized "total project capital cost". Under the same conditions, the highest value of "BE cost" was almost triple of the minimum value, which is $1.93 \mathrm{USD}^{-1}$. The minimum value of "utility cost" is $200.98 \cdot 10^{3}$ USD year $^{-1}$ almost three times less than that obtained with the maximized "BE yield". Moreover, the minimum value of "total production cost" is $9.12 \cdot 10^{6} \mathrm{USD}^{\mathrm{year}}{ }^{-1}$, which is $12 \%$ higher than the value for minimized "BE cost". In those same conditions, the highest value of "total project capital cost" is almost 15\% higher than the minimum value $\left(21.58 \cdot 10^{6} \mathrm{USD}\right)$.

Comparing the optimal conditions of the five responses, it is obvious that the most similar data are "BE yield" and "BE cost", so their joint optimization is presented as the best approach of the BEP process. The same weight has been given to the two responses in an attempt to maximize "BE yield" and minimize "BE cost" under the conditions listed in Table 8, i.e. $165.01^{\circ} \mathrm{C}, 6.63 \%$ $A_{\text {conc }}$, and $15 \% \mathrm{w} \mathrm{v}^{-1}$. Under these circumstances, the "BE cost" increased by less than $0.5 \%$ and the "BE yield" by almost $1 \%$ with respect to the conditions of the individual optimum of the "BE cost", with values of 1.94 USD $1^{-1}$ and $174.12 \mathrm{l} \mathrm{t}^{-1}$ OTP, respectively. The conditions of this optimum were simulated to check the quality of the "RS model", and the results are also included in Table 8. A comparison of "RS model" and simulation shows that the reproducibility of the responses "BE yield", "BE cost", "total production cost", and "total project capital cost" is $99 \%$, and the "utility costs" is around $94 \%$.

\section{OTP and enzyme cost as techno-economic indicators}

Figure 3 is a compilation of the economic results. The distribution of the BEP costs (Figure 3a), where "total raw material cost" has the largest contribution with $31 \%$,

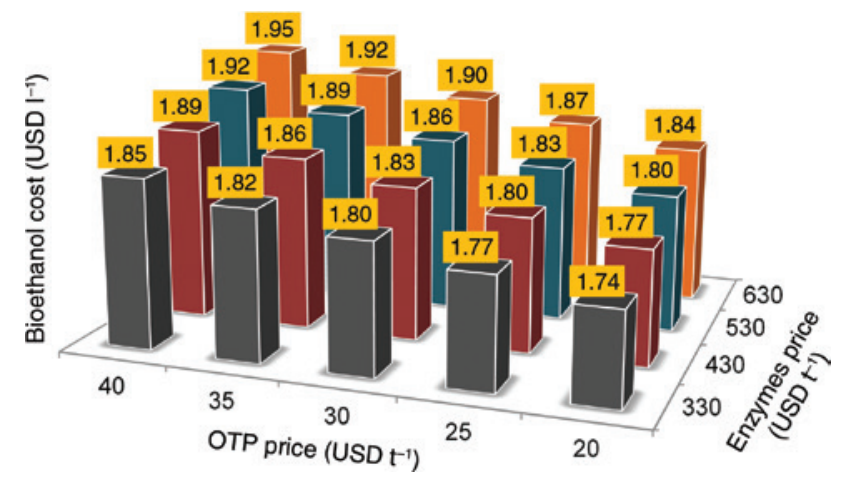

Figure 4: Effect of the OTP and enzymes prices on the final cost of BE.

followed by "depreciation", "operating labor cost" and "total utility cost", with values between 13 and 20\%, representing a total of almost $80 \%$. These values are similar to those published by Cardona et al. (2018). On the other hand, it is also visible how the raw materials cost is distributed (Figure 3b), where the cost of "OTP" and that of "enzymes" are very prominent, with 38.03\% and 34.63\%, respectively, followed by "water" with $14.51 \%$, and the sum of these parameters amounts to $\approx 90 \%$. Liu et al. (2016) came to similar results.

The most influential factors in the BEP cost calculation are the prices of OTP and the enzymes. The sensitivity of the calculations to these factors are presented in Figure 4. Provided the realistic case that the price for OTP and enzymes could have been halved (Linde et al.

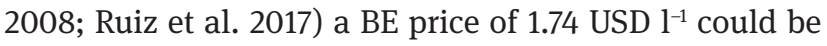
achieved, corresponding to a cost reduction around $12 \%$.

\section{Conclusions}

The raw material cost has a strong influence in the economic feasibility of bioethanol production (BEP) from 
OTP. Clearly, a stand-alone process for ethanol production is not competitive. The process based on the principles of biorefinery, in which more values added products could be merchandized, would increase the economic feasibility of BEP. For example, production of antioxidants, lignins, oligosaccharides, and xylitol from the preextractives are conceivable and would be advantageous for the process economy. The response surface methodology was suitable to select the best parameters to find a techno-economic optimum of the BEP from OTP. Future works should be focused on different scenarios for the development of biorefinery based OTP utilization.

Author contributions: All the authors have accepted responsibility for the entire content of this submitted manuscript and approved submission.

Research funding: This work has been partially financed by the Secretaría de Estado de Investigación, Desarrollo e Innovación, Funder Id: 10.13039/501100007136 and Spanish Ministerio de Economía y Competitividad (ref. ENE2014-60090-C2 and ENE2017-85819-C2, including FEDER funds). JCST and CAC thank Departamento Administrativo de Ciencia, Tecnología e Innovación, Funder Id: 10.13039/100007637 (Colciencias. grant no. 761 Jóvenes Investigadores) and the Facultad de Ingeniería y Arquitectura of the Universidad Nacional de Colombia at Manizales (grant no. 206010012730) for the support. JMRG gratefully acknowledges the postdoctoral scholarship received from Junta de Andalucía.

Employment or leadership: None declared.

Honorarium: None declared.

Conflict of interests: The authors declare that they do not have any conflict of interests.

\section{References}

Al-Malah, K. Aspen Plus: Chemical Engineering Applications. 1st ed. Wiley, Hoboken, New Jersey, 2017.

BP. BP Statistical Review of World Energy BP Statistical Review of World Energy. London, UK, 2017.

Cardona, C.A., Solarte-Toro, J.C., Tamayo, J.A., Castro, A., García, B.A. (2017) Palm oil for food or biodiesel: a disjunction in tropical countries. Adv. Chem. Res. 32:1-36.

Cardona, C.A., Solarte-Toro J.C., Peña A.G. (2018) Fermentation, thermochemical and catalytic processes in the transformation of biomass through efficient biorefineries. Catal. Today 302:61-72.

Carvajal, J.C., Peña A.G., Cardona, C.A. (2016) Comparison of lignin extraction processes: economic and environmental assessment. Bioresour. Technol. 214:468-476.

Claassen, P.A.M., van Lier, J.B., Lopez Contreras, A.M., van Niel, E.W.J., Sijtsma, L., Stams A.J.M., de Vries, S.S., Weusthuis, R.A.
(1999) Utilisation of biomass for the supply of energy carriers. Appl. Microbiol. Biot. 52:741-755.

Daza-Serna, L.V., Solarte-Toro, J.C., Serna-Loaiza, S., Chacón-Perez, Y., Cardona, C.A. (2016) Agricultural waste management through energy producing biorefineries: the Colombian case. Waste. Biomass. Valori. 1-10.

Del Campo, I., Alegría, I., Zazpe, M., Echeverría, M., Echeverría, I. (2006) Diluted acid hydrolysis pretreatment of agri-food wastes for bioethanol production. Ind. Crop. Prod. 24: 214-221.

ePURE. (2015) European Renewable Ethanol: State of the Industry Report. Energy.

Eurostat. (2017) World Energy Statistics 2017 Edition.

Flach B., Lieberz A., Rossetti A. (2017) EU Annual Biofuels Annual 2017. USDA Foreign Agricultural Service: 1-44.

Ghanta, M., Fahey, D.R., Busch, D.H., Subramaniam, B.U. (2013a) Propylene oxide: comparative economic and environmental assessments of $\mathrm{H}_{2} \mathrm{O}_{2}$ based and tertiary butyl hydroperoxidebased propylene oxide technologies. Rep. Carcinog. 12:268-277.

Ghanta, M., Ruddy, T., Fahey, D., Busch, D., Subramaniam, B.U. (2013b) Is the liquid-phase $\mathrm{H}_{2} \mathrm{O}_{2}$ based ethylene oxide process more economical and greener than the gas-phase $\mathrm{O}_{2}$ based silver-catalyzed process ? Ind. Eng. Chem. Res 52:18-29.

Gioti-Papadaki, O. (2012) European Environmental Policy and the Strategy ‘Europe 2020'. Reg. Sci. Inquiry J. 4:151-158.

Granato, D., De Araújo, C., Jarvis, B. (2014) Observations on the use of statistical methods in food science and technology. Food. Res. Int. 55:137-149.

Hernández, V., Romero-García, J.M., Dávila, J.A., Castro, E., Cardona, C.A. (2014) Techno-economic and environmental assessment of an olive stone based biorefinery. Resour. Conserv. Recy. 92:145-150.

Humbird, D., Davis, R., Tao, L., Kinchin, C., Hsu, D., Aden, A., et al. (2011) Process design and economics for biochemical conversion of lignocellulosic biomass to ethanol. Renew. Energ. 303:1-147.

IEA, International Energy Agency. (2017) Key World Energy Statistics 2017.

Indicative Chemical Prices A-Z. http://www.icis.com/chemicals/ channel-info-chemicals-a-z/ (November 20, 2016).

Kamm, B., Kamm, M. (2004) Principles of biorefineries. App. Microbiol. Biot. 64:137-145.

Koizumi, T. (2015) Biofuels and food security. Renew. Sust. Energ. Rev. 52:829-841.

Linde, M., Jakobsson, E.L., Galbe, M., Zacchi, G. (2008) Steam pretreatment of dilute $\mathrm{H}_{2} \mathrm{SO}_{4}$-impregnated wheat straw and SSF with low yeast and enzyme loadings for bioethanol production. Biomass Bioenerg. 32:326-332.

Liu, G., Zhang, J., Bao, J. (2016) Cost evaluation of cellulase enzyme for industrial-scale cellulosic ethanol production based on rigorous Aspen Plus modeling. Bioprocess Biosyst. Eng. 39:133-140.

Macrelli, S., Mogensen, J., Zacchi, G. (2012) Techno economic evaluation of 2 nd generation bioethanol production from sugar cane bagasse and leaves integrated with the sugar based ethanol process. Biotechnol. Biofuels 5:22.

Manzanares, P., Ruiz, E., Ballesteros, M., Negro, M.J., Gallego, F.J., López-Linares, J.C., Castro, E. (2017) Residual biomass potential in olive tree cultivation and olive oil industry in Spain: valorization proposal in a biorefinery context. Spanish J. Agric. Res. 15:1-12. 
Martínez-Patiño, J.C., Romero, I., Ruiz, E., Cara, C., Romero-García, J.M., Castro, E. (2017) Design and optimization of sulfuric acid pretreatment of extracted olive tree biomass using response surface methodology. BioResources 12:1779-1797.

Moncada, J., Tamayo, J.A., Cardona, C.A. (2014) Integrating first, second, and third generation biorefineries: Incorporating microalgae into the sugarcane biorefinery. Chem. Eng. Sci. 118:126-140.

Moncada, J., Aristizábal, V., Cardona, C.A. (2016) Design strategies for sustainable biorefineries. Biochem. Eng. J. 116:122-134.

Myers, R., Montgomery, D., Anderson-Cook, C. Response Surface Methodology: Process and Product Optimization Using Designed Experiments. 4th ed. Wiley, Hoboken, New Jersey, 2016.

NIS, National Institute of Statistics. (2017) Encuesta Trimestral de Coste Laboral (ETCL): Segundo Trimestre de 2017. Spain.

Nowak, A.P., Hagberg, J., Leijonmarck, S., Schweinebarth, H., Baker, D., Uhlin, A., Tomani, P., Lindbergh, G. (2017) Lignin-based carbon fibers for renewable and multifunctional lithium-ion battery electrodes. Holzforschung 72:81-90.

NREL, National Renewable Energy Laboratory. (2017) Biomass Compositional Analysis Laboratory Procedures. Washington D.C, EE.UU. https://www.nrel.gov/.

Olivier, J.G.J., Janssens-Maenhout, G., Muntean, M., Peters, J.A.H.W. (2016) Trends in Global CO Emissions: 2016 Report. The Hague: PBL Netherlands Environmental Assessment Agency; Ispra: European Commission, Joint Research Centre.

Paz-Astudillo, I.C. Diseño integral de biorreactores continuos de tanque agitado aplicados a procesos de fermentación. Universidad Nacional de Colombia - Sede Manizales, 2010.

Pfaltzgraff, L.A., Clark, J. (2014) Green chemistry, biorefineries and second generation strategies for re-use of waste: an overview. In: Advances in Biorefineries: Biomass and Waste Supply Chain Explotation, Ed. K.W. Waldron, pp. 3-33.

Quintero, J.A., Cardona, C.A. (2011). Process simulation of fuel ethanol production from lignocellulosics using aspen plus. Ind. Eng. Chem. Res. 50:6205-6212.

Quintero, J.A., Cardona, C.A., Felix, E., Moncada, J., Sánchez, Ó.J., Gutiérrez, L.F. (2012) Techno-economic analysis of bioethanol production in Africa: Tanzania case. Energy 48:442-454.

Quintero, J.A., Moncada, J., Cardona, C.A. (2013) Techno-economic analysis of bioethanol production from lignocellulosic residues in Colombia: a process simulation approach. Bioresour. Technol. 139:300-307.

REN21 (2016) Renewable Energy Policy Network for the 21st Century. Renewables 2016 Global Status Report. Paris.
Rodrigues, F., Pimentel, F.B., Oliveira, M.B.P.P. (2015) Olive byproducts: challenge application in cosmetic industry. Ind. Crops Prod. 70:116-124.

Romero-García, J.M., Niño, L., Martínez-Patiño, C., Álvarez, C., Castro, E., Negro, M.J. (2014) Biorefinery based on olive biomass. State of the art and future trends. Bioresour. Technol. 159:421-432.

Roselló-Soto, E., Koubaa, M., Moubarik, A., Lopes, R.P., Saraiva, J.A., Boussetta, N., Grimi, N., Barba, F.J. (2015) Emerging opportunities for the effective valorization of wastes and by-products generated during olive oil production process: non-conventional methods for the recovery of high-added value compounds. Trends. Food. Sci. Technol. 45:296-310.

Ruiz, E., Romero-García, J.M., Romero, I., Manzanares, P., Negro, M.J., Castro, E. (2017) Olive-derived biomass as a source of energy and chemicals. Biofuels Bioprod. Biorefining 11: 1077-1094.

Shuit, S.H., Tan, K.T., Lee, K.T., Kamaruddin, A.H. (2003) Oil palm biomass as a sustainable energy source: a Malaysian case study. Energy 34:1225-1235.

Silva, E.A.B., Zabkova, M., Araújo, J.D., Cateto, C.A., Barreiro, M.F., Belgacem, M.N., Rodrigues, A.E. (2009) An integrated process to produce vanillin and lignin-based polyurethanes from Kraft lignin. Chem. Eng. Res. Des. 87:1276-1292.

Singh, S., Ghatak, H. (2017) Process optimization of lignin conversion into value added chemicals by thermochemical pretreatment and electrooxidation on a stainless steel anode. Holzforschung 72:187-199.

Surendra, K.C., Takara, D., Hashimoto, A.G., Khanal, S.K. (2014) Biogas as a sustainable energy source for developing countries: opportunities and challenges. Renew. Sustain. Energy Rev. 31:846-859.

Talhaoui, N., Taamalli, A., Gómez-Caravaca, A.M., FernándezGutiérrez, A., Segura-Carretero, A. (2015) Phenolic compounds in olive leaves: analytical determination, biotic and abiotic influence, and health benefits. Food Res. Int. 77:92-108.

Vázquez-Ojeda, M., Segovia-Hernández, J.G., Ponce-Ortega, J.M. (2013) Incorporation of mass and energy integration in the optimal bioethanol separation process. Chem. Eng. Technol. 36:1865-1873.

Yoshikawa, T., Yagi, T., Shinohara, S., Fukunaga, T., Nakasaka, Y., Tago, T., Takao, M. (2012) Production of phenols from lignin via depolymerization and catalytic cracking. Fuel Process. Technol. 108:69-75. 